\title{
Serum immunoreactive trypsin and pancreatic lipase in primary biliary cirrhosis
}

\author{
V FONSECA, O EPSTEIN,* A KATRAK, D JUNGLEE, DP MIKHAILIDIS, \\ N MCINTYRE, * P DANDONA
}

From the Departments of Chemical Pathology and Human Metabolism, and *Medicine, Royal Free Hospital and School of Medicine, London

SUMMARY Immunoreactive trypsin concentration and pancreatic lipase activity were measured in the sera of 33 patients with primary biliary cirrhosis. Immunoreactive trypsin was increased (above the normal range) in $16(48 \%)$ and pancreatic lipase activity in $18(55 \%)$ patients. Both enzymes were $\omega_{\infty}^{\mathscr{D}}$ increased in $10(30 \%)$ patients. Twenty four patients $(73 \%)$ had an increase of either one or both $ᄋ$ enzymes. There was a significant correlation between immunoreactive trypsin and pancreatic lipase activity. This abnormality was not related to treatment with D-penicillamine, the age of the patients, $\subseteq$ the stage of the disease, or the severity of cholestasis. Thus most patients with primary biliary $\mathbb{\Phi}$ cirrhosis have increased pancreatic enzyme activity and immunoreactive trypsin concentration in $\vec{\emptyset}$ their sera. These data are indicative of damage to the exocrine pancreas. The cause of this damage $\infty$ is as yet unknown.

Abnormalities of exocrine pancreatic function have been previously described in primary biliary cirrhosis. ${ }^{1}$ Although basal trypsin concentrations in the duodenal juice of these patients were normal, the response to stimulation with secretin-pancreozymin was impaired. ${ }^{1}$

We have previously shown that serum immunoreactive trypsin concentrations and pancreatic lipase activity are abnormal in several disease states that affect the pancreas, with and without clinical manifestations of pancreatic deficit. ${ }^{2-11}$ As serum immunoreactive trypsin and pancreatic lipase activity have not previously been assessed in primary biliary cirrhosis, we investigated the respective concentration and activity of these enzymes in this condition. We also assessed whether serum immunoreactive trypsin and pancreatic lipase activity correlated with severity of the liver disease and whether treatment with Dpenicillamine changed serum immunoreactive trypsin and pancreatic lipase activity.

\section{Patients and methods}

Thirty three patients (three men and 30 women) with histologically confirmed primary biliary cirrhosis ${ }^{12}$ were included in the study. The median age was 59 years (range 49-70). Plasma alkaline phosphatase

Accepted for publication 23 January 1986. activity was raised in all the patients (median $517 ;$ range 217-2008 U/1), and plasma bilirubin was raised ( $>17 \mu \mathrm{mol} / \mathrm{l}$ ) in 15 patients. The reference ranges for ${ }^{\Phi}$ plasma alkaline phosphatase activity and bilirubin $\overrightarrow{\vec{P}}$ concentration in our routine chemical pathology lab-윽 oratory are $35-130 \mathrm{U} / \mathrm{l}$ and 5-17 $\mu \mathrm{mol} / 1$, respectively.

COLLECTION OF BLOOD SAMPLES AND ASSAYS Venous blood was obtained without stasis during out $-\frac{0}{0}$ patient follow up visits. Blood was allowed to clot and the serum separated and stored at $-20^{\circ} \mathrm{C}$. Serum? immunoreactive trypsin was measured by radio-尺̊ immunoassay (double antibody technique) using a kit $₹$ (Hoechst, Hounslow, United Kingdom). ${ }^{24}$ Serum을 pancreatic lipase activity was measured ${ }^{3}$ using a kit $>$ (Boehringer, Lewes, Sussex, United Kingdom) based을. on a turbidimetric method in which a triolein suspension is the substrate. The serum was stored at $-20^{\circ} \mathrm{C}$ until the time of assay in a single batch. In our $N$ previous experience ${ }^{2-10}$ we found immunoreactive trypsin and pancreatic lipase activity values to be sta- ble at this temperature for up to six months, providedo the samples were not thawed.

Blood was also collected in heparinised tubes and $\stackrel{\mathscr{S}}{+}$ the plasma assayed for total bilirubin, albumin, and 0 alkaline phosphatase activity using a SMAC-O뭉 Technicon autoanalyser. These assays were carried $\stackrel{\Phi}{\Phi}$ out on the same day as the outpatient visit. The refer- $\mathbb{Q}$ ence range for plasma albumin was $35-50 \mathrm{~g} / \mathrm{l}$. The 


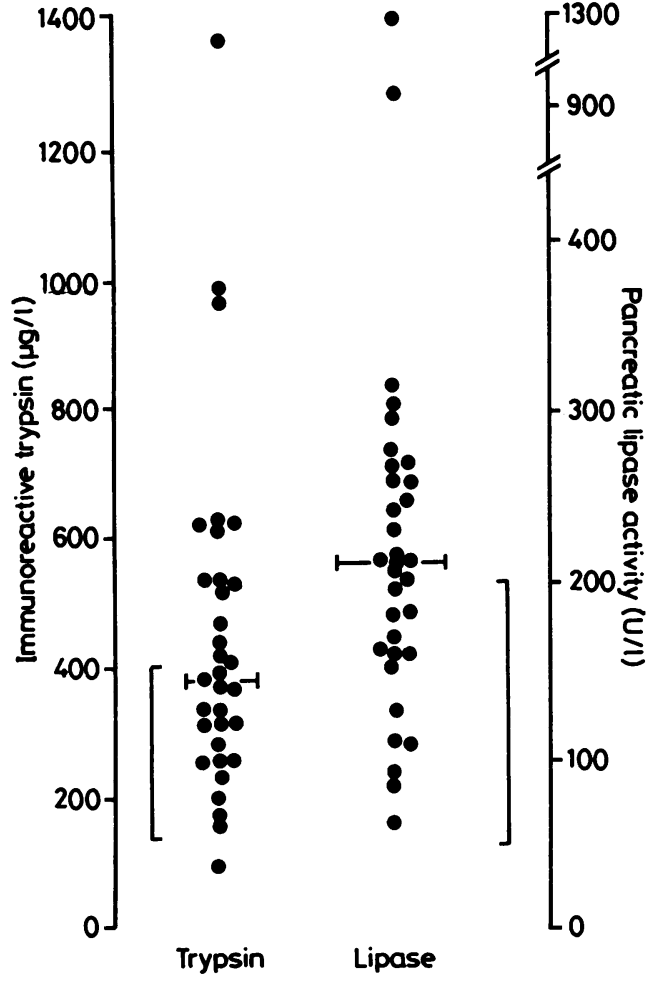

Figure Serum immunoreactive trypsin concentration and pancreatic lipase activity in patients with primary biliary cirrhosis. Parentheses show normal range.

reference ranges in our laboratory for serum immunoreactive trypsin and pancreatic lipase activity in adults are $140-400 \mu \mathrm{g} / 1$ and $50-200 \mathrm{U} / 1$, respectively.

Statistical analysis was carried out using the MannWhitney U test (two tailed) for non-parametric data. Correlation studies were done using linear regression analysis.

\section{Results}

Serum immunoreactive trypsin concentrations were raised (above the normal range) in $16(48 \%)$ patients and serum pancreatic lipase activity was raised in 18 $(55 \%)$. In $10(30 \%)$ both immunoreactive trypsin and pancreatic lipase activity were raised. Thus in 24
(73\%) patients either serum immunoreactive trypsin or pancreatic lipase activity, or both, were raised. The median immunoreactive trypsin concentration (395 $\mu \mathrm{g} / \mathrm{l})$ was at the upper end of the normal range, while the median pancreatic lipase activity $(210 \mathrm{U} / \mathrm{l})$ was greater than the upper end of the normal range (Figure). Serum immunoreactive trypsin was subnormal in one patient $(3 \%)$ who had concomitant insulin dependent diabetes. Although some patients had a raised immunoreactive trypsin concentration with normal pancreatic lipase activity, or vice versa, there was a significant correlation between immunoreactive trypsin and pancreatic lipase activity $(r=0.56 ; p<$ 0.01 ).

There was no significant correlation between serum immunoreactive trypsin or pancreatic lipase activity and indices of liver function: plasma alkaline phosphatase activity, plasma bilirubin, or plasma albumin concentrations. Some patients with total plasma bilirubin concentrations within the normal range had raised serum immunoreactive trypsin concentrations and pancreatic lipase activity (Table). The stage of the disease $^{12}$ (Table), the presence of "sicca" syndrome ${ }^{12}$ (such as dry eyes and mouth with or without arthritis), and D-penicillamine treatment did not affect pancreatic enzymes.

The median immunoreactive trypsin concentration in patients with primary biliary cirrhosis below the age of 59 (the median age of these patients) was $470 \mu \mathrm{g} / \mathrm{l}$, which was higher (though not significantly higher) than in patients whose age was more than 59 (326 $\mu \mathrm{g} / \mathrm{l})$. Similarly, the median pancreatic lipase activity in patients below the age of 59 was $245 \mathrm{U} / 1$, which was higher (though not significantly higher) than in patients whose age was above $59(214 \mathrm{U} / \mathrm{l})$.

\section{Discussion}

This study shows that either serum immunoreactive trypsin concentration or pancreatic lipase activity are above normal in $73 \%$ of patients with primary biliary cirrhosis. The only patient who had a subnormal immunoreactive trypsin concentration had concomitant insulin dependent diabetes mellitus, a condition in which we have previously reported subnormal activities of this enzyme. ${ }^{4}$

We have shown previously that pancreatic enzyme

Serum immunoreactive trypsin and pancreatic lipase activity (median and range) in patients with primary biliary cirrhosis

\begin{tabular}{|c|c|c|c|c|c|c|c|c|}
\hline & \multicolumn{2}{|c|}{ D-penicillamine } & \multicolumn{2}{|l|}{ "Sicca" } & \multicolumn{2}{|l|}{ Stage } & \multicolumn{2}{|c|}{ Biliburin (umol/l) } \\
\hline & $\begin{array}{l}Y e s \\
(n=13)\end{array}$ & $\begin{array}{l}\text { No } \\
(n=20)\end{array}$ & $\begin{array}{l}Y e s \\
(n=20)\end{array}$ & $\begin{array}{l}N o \\
(n=8)\end{array}$ & $\begin{array}{l}\text { Early* } \\
(n=8)\end{array}$ & $\begin{array}{l}\text { Late } \\
(n=15)\end{array}$ & $\begin{array}{l}<34 \\
(n=13)\end{array}$ & $\begin{array}{l}>34 \\
(n=20)\end{array}$ \\
\hline $\begin{array}{l}\text { Immunoreactive trypsin } \\
(\mu \mathrm{g} / \mathrm{l}) \\
\text { Pancreatic lipase } \\
(\mathrm{U} / \mathrm{l})\end{array}$ & $\begin{array}{l}439 \\
(100-968) \\
210 \\
(91-1300)\end{array}$ & $\begin{array}{l}347 \\
(172-1353) \\
198 \\
(63-935)\end{array}$ & $\begin{array}{l}402 \\
(174-1353) \\
230 \\
(86-1300)\end{array}$ & $\begin{array}{l}289 \\
(100-628) \\
200 \\
(63-264)\end{array}$ & $\begin{array}{l}402 \\
(172-983) \\
214 \\
(63-1300)\end{array}$ & $\begin{array}{l}406 \\
(100-1353) \\
214 \\
(91-965)\end{array}$ & $\begin{array}{l}373 \\
(174-1353) \\
231 \\
(105-1300)\end{array}$ & $\begin{array}{l}390 \\
(100-983) \\
211 \\
(63-315)\end{array}$ \\
\hline
\end{tabular}

"“Early" primary biliary cirrhosis is defined as stage I and stage II on hepatic histology "2. "late" primary biliary cirrhosis as stages III and IV. 
activity may be increased in the absence of clinically overt pancreatitis in the elderly ${ }^{10}$; in patients with cystic fibrosis ${ }^{23}$ or thalassaemia major, ${ }^{78}$ and in those receiving high doses of methylprednisolone. ${ }^{11}$ This abnormality was thought to reflect a breakdown of the "acinar-blood barrier," with consequent leakage of pancreatic enzymes and their proenzymes into the blood.

The increased pancreatic enzymes in patients with primary biliary cirrhosis are unlikely to be caused by an age related phenomenon. The median immunoreactive trypsin and pancreatic lipase activity in patients below the age of 59 was higher than that in patients above 59 years. Furthermore, our normal range is based on a large population up to the age of 65 . In addition, the elderly patients included in our study reporting increased activities of pancreatic enzymes were much older (median age 77.5 years, range $67-98$ years) ${ }^{10}$ than the patients with primary biliary cirrhosis in this study (median age 59 years, range 49-70 years).

Cholestasis is unlikely to have made a major contribution to the raised pancreatic enzyme activities, as there was no correlation between serum immunoreactive trypsin or pancreatic lipase activity and plasma bilirubin or alkaline phosphatase in this study, and patients with raised pancreatic enzyme activities had normal, mildly, or severely raised plasma bilirubin concentrations.

Patients treated with D-penicillamine had higher immunoreactive trypsin concentrations than untreated patients. Although this difference was not significant, it is relevant that cases of acute pancreatitis associated with D-penicillamine treatment have been reported. ${ }^{13}$ Animal experiments have also shown that this drug causes exocrine pancreatic dysfunction. ${ }^{14}$

Serum immunoreactive trypsin and pancreatic lipase activity did not differ when patients were classified according to their stage of disease as determined by liver biopsy. ${ }^{12}$ This suggests that pancreatic damage is not dependent on, and does not parallel, histological changes in the liver.

Although there was a significant correlation between serum immunoreactive trypsin and pancreatic lipase activity in our patients, both enzymes were often not concomitantly raised. This discrepancy is probably due to the fact that the immunoreactive trypsin radioimmunoassay also measures trypsinogen; pancreatic lipase activity estimation, on the other hand, is based on enzymatic activity only. We have previously observed a similar discrepancy between immunoreactive trypsin and pancreatic lipase activity in $\beta$-thalassaemia major with iron overload. ?

Our findings of raised immunoreactive trypsin and primary biliary cirrhosis concentrations can be interpreted as evidence that exocrine pancreatic damage occurs in a large proportion of patients with primary biliary cirrhosis. This assumption is based on the $\stackrel{\stackrel{0}{5}}{\overrightarrow{5}}$ finding of raised serum concentrations of immuno- 으․ reactive trypsin and pancreatic lipase activity in acute $\overrightarrow{\vec{F}}$ pancreatitis, ${ }^{15}$ in early cystic fibrosis-that is, pre- $\stackrel{0}{\rightarrow}$ ceding the well documented functional pancreatic fail- $\frac{}{c}$ ure which occurs in this disease ${ }^{23}$-and following the administration of high doses of methylprednisolone (which are thought to be a risk factor for acute pan- $\stackrel{\Phi}{\varrho}$ creatitis). ${ }^{11}$ Pancreatic secretion of enzymes following $\aleph^{\circ}$ stimulation with secretin-pancreozymin has also been $\overrightarrow{0}$ shown to be impaired in primary biliary cirrhosis. ${ }^{1}$

The mechanism causing the postulated pancreatic $\vec{\omega}$ damage is not clear, but it is probably not directly related either to the histological changes in the liver, 8 treatment with D-penicillamine, or the degree of $\omega_{0}$ abnormality of liver function.

We thank Pamela Dale for secretarial help.

\section{References}

${ }^{1}$ Epstein O, Chapman RWG, Lake-Bakaar G, Foo AY, Rosalki SB Sherlock $S$. The pancreas in primary biliary cirrhosis and pri- $\vec{\theta}$ mary sclerosing cholangitis. Gastroenterology 1982;83:1177-82.

${ }^{2}$ Dandona P, Hodson ME, Ramdial L, Bell J, Beldon I, Batten JC. Serum immunoreactive trypsin in cystic fibrosis. Thorax 1981;38:60-2.

${ }^{3}$ Junglee D, Katrak A, Penketh A, Hodson ME, Batten JC, Dandona P. Serum pancreatic lipase in cystic fibrosis. $\mathrm{Br}$ Med J 1983;286:1693-5.

${ }^{4}$ Dandona P, Elias E, Beckett AG. Serum trypsin levels in diabetes mellitus. Br Med J 1978;i:1125-6.

${ }^{5}$ Dandona P, Freedman DB, Foo Y, et al. Exocrine pancreatic function in diabetes mellitus. J Clin Pathol 1984;37:302-6.

${ }^{6}$ Junglee D, de Albarran R, Katrak A, Freedman DB, Beckett AG, Dandona P. Pancreatic lipase concentration in diabetes mellitus. J Clin Pathol 1983;36:200-2.

${ }^{7}$ Hussain MA, Dandona P, Fedail M, Flynn DM, Hoffbrand AV. Serum immunoreactive trypsin in thalassaemia major. $J$ Clin Pathol 1981;34:970-1.

${ }^{8}$ Junglee D, Katrak A, Hoffbrand AV, Dandona P. Serum pancreatic lipase in thalassaemia major. Clin Chem 1983;29:2003-4.

${ }^{9}$ Mikhailidis DP, Foo Y, Ramdial L, Kirk RM, Rosalki SB, Dandona $P$. Pancreatic exocrine function after truncal and highly selective vagotomy. J Clin Pathol 1983;34:963-4.

${ }^{10}$ Mohiuddin J, Katrak A, Junglee D, Green M, Dandona P. Serum D pancreatic enzymes in the elderly. Ann Clin Biochem 1984:21:102-14.

${ }^{11}$ Dandona P, Junglee D, Katrak A, Fonseca V, Havard CW. Serum $\mathcal{N}$ pancreatic enzymes increase following methylprednisolone: pos- $\mathrm{N}$ sible evidence of subclinical pancreatitis. Br Med J 1985;291:24. ?

${ }^{12}$ Sherlock S, Scheuer PJ. The presentation and diagnosis of $100 \mathrm{\omega}$ patients with primary biliary cirrhosis. $N$ Engl $J$ Med $\sigma$ 1973;289:674-8.

13 Data Sheet Compendium (ABPI) 1983-84. Baily B, ed. London: 을 Datapharm Publications, 1983:785.

${ }^{14}$ Argent BE, Case RM, Smith PA, Sunter JP. The effect of chronic administration of D-penicillamine on the rat pancreas. $B r J$ Pharmacol 1977;61:120P-1P.

${ }^{15}$ Elias E, Redshaw M, Wood T. Diagnostic importance of changes $\overrightarrow{\overparen{D}}$ in circulating concentrations of immunoreactive trypsin. Lancet 1977;ii:66-8.

Requests for reprints to: Dr P Dandona, Metabolic Unit, Department of Chemical Pathology and Human Metabolism, Royal Free Hospital and School of Medicine, London NW3 2QG, England. 